\title{
EXPLORING THE CORNERSTONE FACTORS THAT CAUSE WATER SCARCITY IN SOME PARTS OF AFRICA, POSSIBLE ADAPTATION STRATEGIES AND A QUEST IN FOOD SECURITY
}

\author{
Sharmaarke A. Musse ${ }^{1 *}$ \\ 1* Department of Environmental Science, University of Hargeisa, Somaliland Email: \\ jamaal_77@hotmail.co.uk; Contact@uoh.edu.so
}

Sept-2018

Key Words: Water scarcity, Water Withdrawal, food security, Water Management, Climate Change, adaptation

Corresponding author: ${ }^{1}$ Sharmake Abdi Musse, Department of Environmental Science, University of Hargeisa, Somaliland.Tel: +25263-4449356Email: jamaal_77@hotmail.co.uk

\section{ABSTRACT}

Water scarcity is significantly increasing water stress in Africa and some parts of the world. This is due to human induced factors such as climate change, increase of human population that raises demand which outstrips food availability, and put great changes of land use which results in changes of hydrological mechanics and water availability as whole. The investigation was through literature review and it tries to examine the criticality of water scarcity in Africa regions, and the major factors that mastermind this menace. Also possible strategies that can be promptly used to manage water scarcity at domestic level and in agriculture are described in this paper, not with standing the fact that agriculture sectors in Africa and the rest of the world remain the utmost vulnerable enterprise to water scarcity and withdrawal on the planet earth.

\section{INTRODUCTION}

Water is most paramount and necessitated basic need in all life forms in earth planet. It is the blood of the biosphere [1]. Water takes an important role in the socio-economic development, and it is needed in all economic and ecosystem functions. However, water resources are finite and the growing demand of water in various development aspects has increased. The natural and man-made factors have impacted water resource availability and sustainability. Water scarcity is commonly defined as a situation where water availability in a country or in a region is below $1000 \mathrm{~m} 3$ per person per year. Falkenmark's[2] threshold is widely used to indicate water scarcity or stress where the index thresholds $1,700 \mathrm{~m}$ per capita per year are used as the thresholds between water stressed and scarce areas, respectively. Many regions in the world experience 
water scarcity, living with less than $500 \mathrm{~m} 3$ per person per year which could be considered severe water scarcity.

Water scarcity is among the contemporary critical problems in this world, and thus has been ensuing intricate in humanity, ecosystem, agriculture and socio-economic development at large throughout the globe. It is estimated that by 2030, 75 million to 250 million people in Africa will be living in areas of high water stress, which will likely displace anywhere between 24 million and 700 million people as conditions become increasingly unlivable, and Sub-Saharan Africa had the largest number of water-stressed countries of any other place on the planet[3].

Despite the projections and gradual conference on water scarcity issues in Africa and the world at large, global water use continues to expand faster than population growth. Over the past century world population has tripled while water withdrawals have increased more than six fold[4]. Water withdrawals in developing countries for agricultural purposes over the past decade have increased by 4 to 8 percent per year. Water for food security situation is intricate and might get daunting if no action is taken [5].

\section{METHODS}

The study reviewed the literature to define and delineate the focus of environmental water scarcity and food security as a concept that emphasizes the sustainability of the environmental goods with the intent of helping the growing human population to develop more adaptation strategies to water scarcity. It substantiated the importance of water availability to human survival and agricultural sustainability with emphasis on improving adaptation capacity to growing water scarcity. It also examined through some published articles, reports and papers on the water and food security threats in Africa, and the relationship between water scarcity and agricultural production as they relate to food security. Generalized views of the causes of water scarcity and how to overcome this global threat were considered for analysis, with a case study of Africa particularly sub-Saharan region.

\section{DISCUSSIONS}

\subsection{WATER SCARCITY: A CRITICAL IMPACT ON FOOD PRODUCTION}

Water scarcity can cut production and badly impact food security worldwide. The brutality of the water crisis has prompted the United Nations (UNDP, 2007) to conclude that it is water scarcity, not to be deficient in arable land that will be the most important limitation to increased food production over the next few decades. Changes in precipitation and temperature may lead to changes in runoff and water availability, which, in turn, could affect crop productivity [6].

Water shortages will depress agricultural yields, thus posing a severe threat to the global food security. However, this adds pressure on food prices and imports. Reports indicate an increase of food prices in some developing countries, and this is attributed to population growth and a growing stress of water due to increase of water withdrawal for different purposes. The rapid population triggers the water scarcity situation in Africa and world at large as the need for food increases. For example, in 1995, the annual global grain consumption averaged around $300 \mathrm{~kg}$ 
per capita including the consumption of livestock products. If we assume that global grain consumption will remain at this level, simply meeting the grain water requirement of the estimated global population of 10billion in 2025 will require an additional 780 billion $\mathrm{m}^{3}$ of water. The non-grain (fruit and vegetable) portion of the diet may require only one third $\mathrm{s}$ much water to produce as the grain, because it is largely made of water. Thus, the minimum additional amount of water required to meet the food requirements of the 10billion people in 2025 would be 1,040 billion $\mathrm{m}^{3}$. This quantity is equal to more than twelve times the flow of the Nile River [7].Therefore the implication of this figure is that, the water stress will increase for the coming years as the need for additional food increases due to alarming population growth. Despite there will be complexity to meet the required food to feed the growing population in future as the trends of freshwater availability reduces. To lessen the resulting effect of water scarcity in food security, there must be measures aimed at sustaining and conserving the available freshwater and hydrological system at large.

The industrial expansion and the civilization in Africa are also contributory factors that trigger the harmonization of available freshwater and food security, which if not well addressed and balanced this nexus, may lead to food insecurity and famine. Falkenmark \&Rockström et al[8] believes that African famine is too often as result of a set of disturbances to green water security, natural factors, including the susceptibility of the region to interannual drought and the short growing season, exacerbated by soil degradation and other human factors to generate man-made water scarcity.

Growing emissions released into atmosphere, increases greenhouse gases in the atmosphere, and impedes in precipitation, and it would affect agriculture both positively and negatively depending on the crops varieties and the adaptation measures undertaken, despite some studies indicate that African agriculture would mostly negatively affected by climate change.

Despite the growing climate variability and precariousness of rainfall distribution in arid and semi arid regions of Africa, irrigation has contributed significantly in the increase of agricultural yields and stabilization of food production, but there are irrigational methods that adversely affect sustainability of water resources. Increased agricultural production is required for dropping rural poverty and more economic growth. New investments in irrigation infrastructure and enhanced water management can reduce the impact of water scarcity in food security [9]. 


\section{PROJECTIONS ON WATER SCARCITY/STRESS TRENDS IN AFRICA}

As Falkenmark's water availability threshold is widely used. It indicates that if per capita water consumption for certain country is below $1000 \mathrm{~m}^{3}$, that country is under water scarcity; and if it is less than $1700 \mathrm{~m}^{3}$ per capita water consumption, this is considered as water stress situation. In 2025 Africa countries will either be in state of water scarcity, stress or vulnerable to changes in water supply as the projections indicate (fig 1). The summary of Report of the Intergovernmental Panel on Climate Change (IPCC) Synthesis climate change report (2007) states that by 2022 climate in African region will become even hotter and drier, and increase water stress in Africa, and could reduce $50 \%$ of yields from rainfed agriculture. In 2022, about 75 to 250 million people are projected to experience water stress in Africa [10].

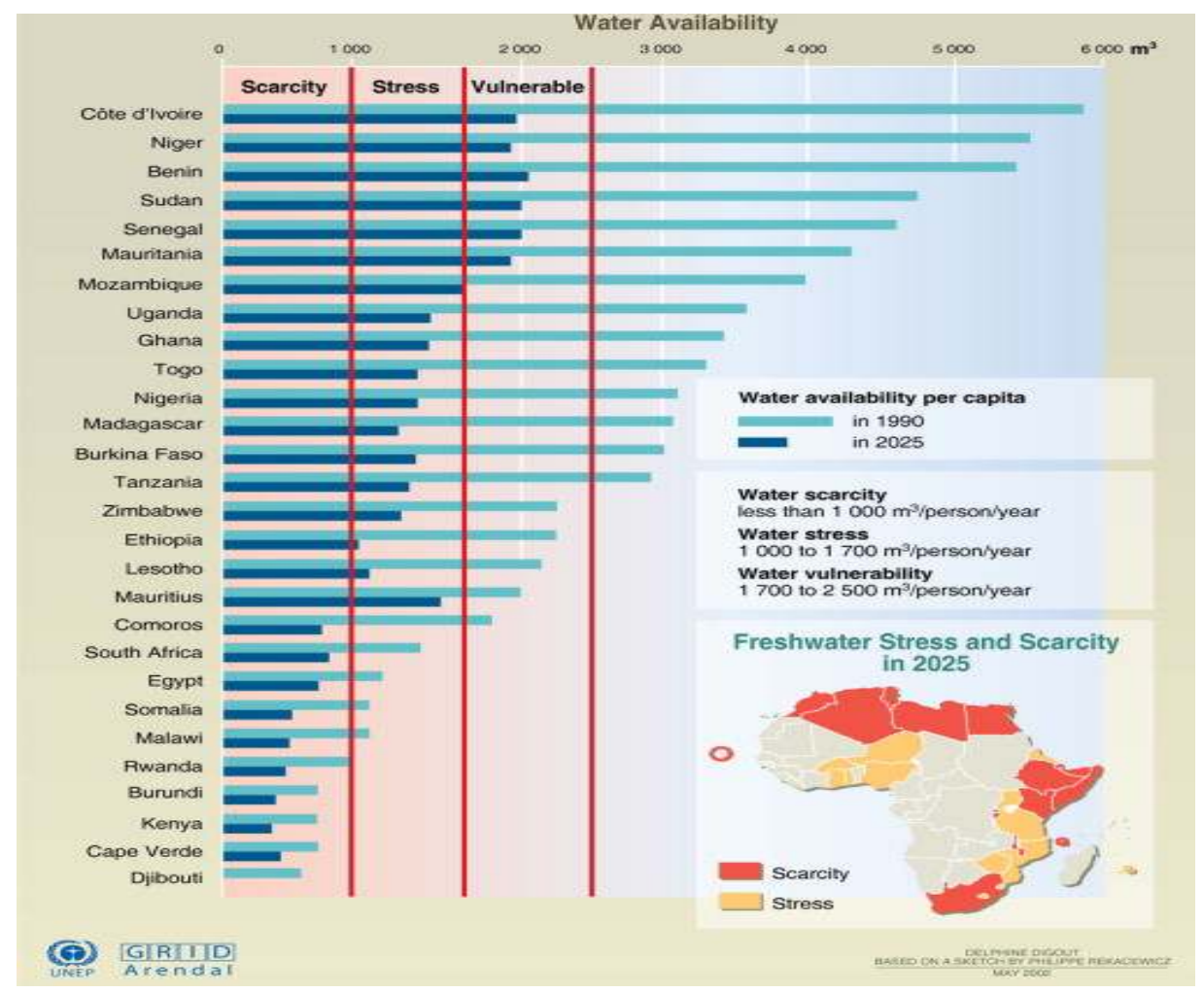

Fig1: Projections on per capita water availability in Africa

\section{Source: UNEP}

However, it is clear that the most of Sub Saharan countries are critically morphing towards severe water scarcity as the human population rapidly increases, and trends on climate change prevail across the globe. Areas used to have sufficient rainwater in Sub-Saharan Africa have tended to suffer uneven and irregular rainfall patterns, and this comes as result of Global climate change and increased natural intervention by mankind. This needs, note worthily a sustainable management of water resource, in particular water application for agriculture as long as the agriculture remains utmost sector that withdraws water. 


\subsection{MAJOR FACTORS THAT CAUSE GROWING WATER SCARCITY IN SOME PARTS OF AFRICA}

Deforestation; the population in Africa is rapidly increasing, and this causes urbanization resulting clearance for land and alteration of natural landscape. Africa is experiencing vast forest loss. As estimated by World Wide Fund for Nature (2017) between 2000 and 2012, only East Africa lost around 6 million hectares of forest. And it is projected that the region will lose 12 million hectares between 2010 and 2030 if current trends continue [11]. However, the reduction of forest cover will cause a change of natural landscape, and most importantly it affects the hydrological cycle. Elizabeth Hunt [12] believes when the landscape characteristics are altered, both the water absorption and release function are diminished. The landscape can capture less rainfall than before, so more water runs off on land and less is conducted through soil into groundwater aquifers. As a result, extremely low flows and water shortages, as well as extremely high flows that cannot be efficiently captured, become more common in the drainage basin.

Desertification: is profound alteration of landscape and has impact on availability and quality of freshwater. When the land is thoroughly denuded through deforestation, creates desertification, and this leads a change in rainfall. Thomas and Middleton at al[13] believe desertification as important factor for growing water scarcity in Africa and the world. The albedo(the ratio of reflected light to total amount of radiation emitted) increases, and this reduces convective rainfall. The evotranspiration also increase as the temperate increase due to reduction of forest coverage that can moderate climate. Meanwhile, according to Chouhan at al[14]the evaporation from water sources increase together with destruction of plant cover, and this contributes to the desiccation of soil and considerable decrease in the soil capacity to retain water, resulting in a substantial increase of runoffs. The evaporation of water from surface reservoirs can substantially reduce downstream water availability [15].

Climate change (Increase of temperature); regions in Africa has been experiencing climate change evidenced by increase of temperature ad recurrent droughts. The temperature of Africa has been increasing (see figure2), and this has impacted freshwater.

According to works of Malhi and Wright[17], A.C Kruger and Showgwe[18], M New[19] and Kinguyu, Ogallo and Anyamba[20] cited in Gordon Conway work[21], the tropical forests have warmed by $0.29^{\circ} \mathrm{c}$ per decade. In southern and western Africa there have been more warm spells and fewer extremely cold days. In eastern Africa temperatures have fallen close to the coasts and major inland lakes. Thus, the increasing of temperature in Africa continent has impacted on fresh water availability and hydrological mechanicals at large scale [22].

On the other hand, as pointed out by (Hulme et al., 2001; Jones and Moberg, 2003; Kruger and Shongwe, 2004; Schreck and Semazzi, 2004; New et al., 2006; IPCC, 2007; Rosenzweig et al., 2007; Trenberth et al., 2007; Christy et al., 2009; Collins 2011;Grab and Craparo, 2011; Hoffman et al., 2011; Mohamed,

Figure2: The Africa mean temperature of anomalies over the past 100 years [16]. 
2011; Stern et al., 2011; Funk et al., 2012;Nicholson et al., 2013) Most parts of Africa, temperatures have increased by $0.5^{\circ} \mathrm{C}$ or more during the last 50 to 100 years with minimum temperatures warming more rapidly than maximum temperatures[23-37].Near surface air temperature anomalies in Africa were significantly higher for the period 1995-2010 compared to the period 1979-1994 [38].

Also there are studies that indicate a substantial evidence of climate change in Africa that impacted abundance of freshwater hence agricultural production. Beck and Bernauer [39] work points out that all countries within the Zambezi River Basin could contend with increasing water shortages due increase of temperature and climate change severity at large. In Zimbabwe, climate change is estimated to increase water shortages for downstream users dependent on the Rozva dam Water shortages are also estimated for the Okavango Delta, from both climate change and increased water withdrawals for irrigation[40-41].

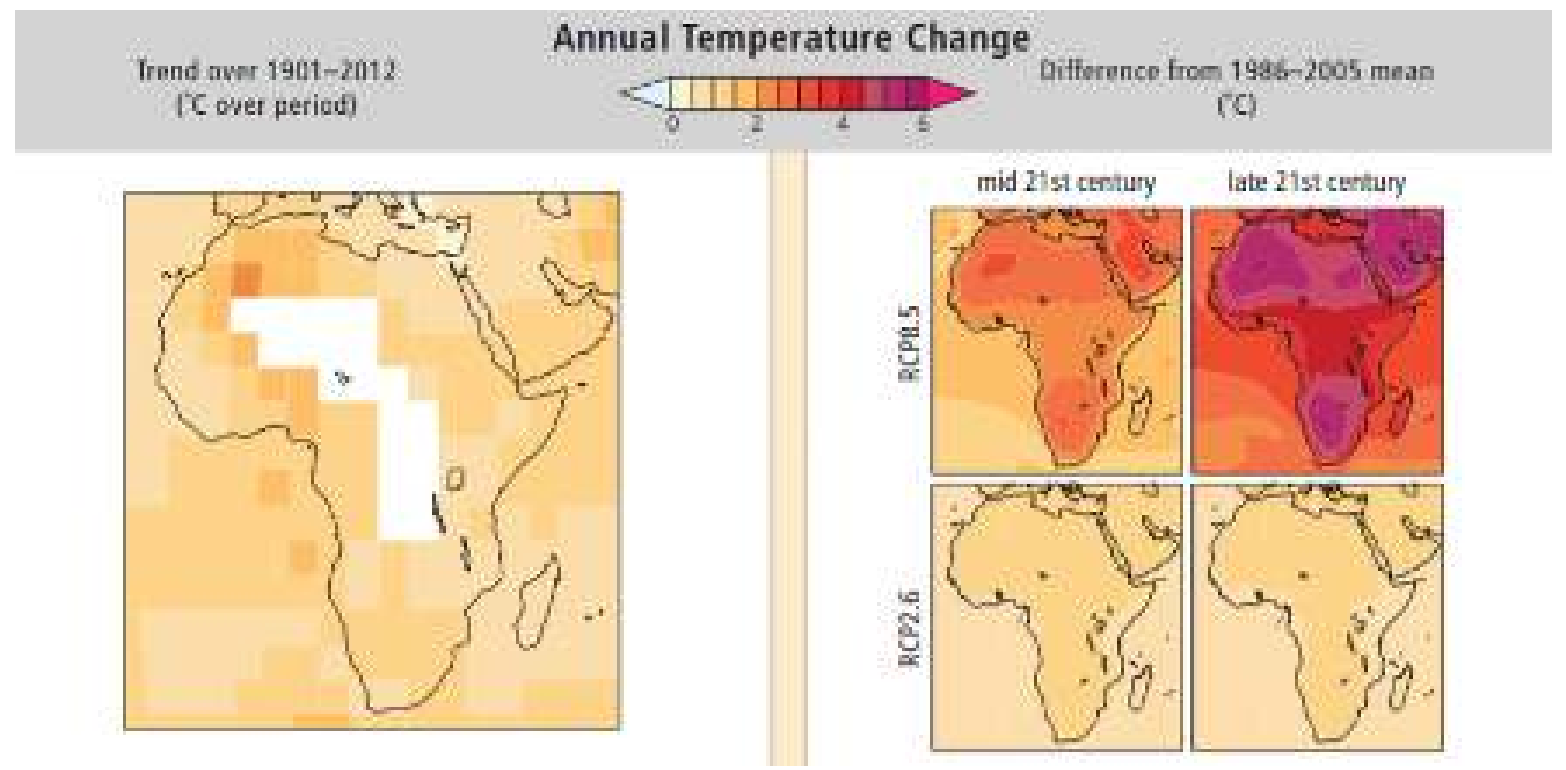

Figure3: trends in annual climate change (temperature in analysis)

Source: IPCC, 2014[42]

The above map demonstrates the prevalence of climate change in Africa particularly the changes in temperature. This stems from a conclusion that the increase of climate change severity in Africa experienced through escalation of temperature, recurrent droughts and raising evaporation has impacted on water resource availability particularly freshwater thereby impeding agricultural production.

Population Increase; the population in Africa has been alarmingly increasing with growth rate of $2.69 \%$ [43]. The implication of this growth rate indicates that water demand and withdrawal for different purposes increases, hence water scarcity. As pointed out by Falkenmark[44], when societal water demands are high in relation to water availability, water is seen as scarce. He also generally categorized as prevailing water scarcity in Africa and World at large due to populationdriven scarcity in which it is implied that more and more people jointly depend on each unit of water (i.e. water crowding); and demand-related scarcity, a term which refers to a level of 
exploitation in which mobilization of even more of the resource becomes increasingly difficult and costly. In his study, climate change considered an important factor for the diminishing of both green and blue water.

Poor utilization of surface runoffs; there are many areas in Africa particularly in Horn of Africa countries( Somalia, Somaliland, Djibouti and Ethiopia) whereby the communities are not in position to efficiently harvest surface runoffs due to poor technology or other social factors that prevents them to efficient utilize rainwater and other potential water sources. The poor utilization of rainwater including runoffs creates water shortages [45]. At times the heavy runoffs carry different objects from the ground into the drinkable water sources, and makes undrinkable. The implication is that, the limited effort in effectively harvesting rainwater by community can be considered as contributory factor to growing water stress in many parts of Africa.

Quality of Soil; the quality of soil also impacts water retention capacity. If soil quality is poor, there will be huge runoffs, and water will fail to infiltrate into ground, hence community is left without water. Similarly this agrees by Malin Falkernmark[46] as he stated out that there may be problems with infiltration. For example soil crusting, so that rain quickly runs off; and the soils may have poor water holding capacity hence water shortage. The formation of hardpans in semiarid and arid areas in Africa reduces the infiltration of water into ground water [47]. Also when rainfall is high and infiltration rate is low because of steep slopes and soil structure which is not letting water to infiltrate into the ground, runoff becomes high and a high quantity of water is lost.

Conflicts; the conflicts that always take place in many parts of Africa causes water scarcity in such a way whereby the community are displaced from their settlements, and nearby water sources. As pointed out by Smith [48] the root of the Darfur conflict is a struggle over controlling an environment that can no longer support all the people who must live in it. However, this stem from many people to encounter severe water and food shortages due to being displaced from their water and food sources.

Poverty; the vulnerability of many African poor countries to adapt to high variability in water resource availability can be contributory factor in the prevalence of water scarcity in many areas. The poor living in irrigated areas are at great risk because of the growing scarcity and competition for water, and the overexploitation of groundwater resources. There are two regions of the world that stand out in terms of the scope and magnitude of rural poverty-South Asia and sub-Saharan Africa. They could not be more contrasting in terms of water resources and irrigation development [49]. The implication is that, the poverty situation in many parts of Africa stems from tremendous poor people not to involve in water and irrigational development activities due to financial constraints. International Water Management Institute (IWMI) puts great emphasize in alleviating poverty and improving the life of poor people as important strategy that enable them to corporately involve in the development of water and irrigational infrastructure.

On the other hand, the Comprehensive Assessment of Water Management in Agriculture (2007) pointed out the prevalence of water scarcity in many parts of Africa due to economic related 
issues whereby the governments and community have inadequate capitals to invest in water sector [50].

Poor withdrawal of water; several studies indicate that in some areas of Africa there are potentials of water resource, but poor infrastructure and limited technological capacity ensues constraints in efficient water withdrawal, thus creating water stress. This is agreed by Bashir[51].He observes that some places in central, East and parts of West Africa water is abundant, but getting it to people is difficult because of lack of infrastructure and capacity. And yet in some places (mostly the Sahelian countries) both the resource base and the capacity to access to water resources are inadequate.

However, the planning of water resources need to be done considering many factors relating to social, economical, political and climate change which adds to water supply uncertainties.

\subsection{MEASURES IN ADAPTING TO GROWING WATER SCARCITY IN AGRICULTURAL SECTOR}

Adaptation of growing water scarcity in agriculture requires an understanding on the agroecological and climatic conditions, farm types and socio-political and institutional arrangements. Adaptation can take place both on-farm and off-farm. Planned adaptation requires government intervention, whereas autonomous adaptation occurs through private agents [52].

In order to sustain agricultural productivity and meet the increasing demand of food resulted by the alarming population growth in Africa, efficient use of water in agriculture and water management at large is an important gist. To achieve this, Pereira et al., [53] finds the use of treated waste water and saline waters in agriculture as way to reduce excessive use of freshwater in agriculture. Similarly this is agreed by Trinch et al[54] as he pointed out that efforts in reusing waste water as an option to cope with water scarcity. Also other farm level adaptation practices include crop diversification and the use of sustainable irrigational methods that minimize water withdrawal. Naomi et al, [55] observes the need to establish an optimal choice of irrigation system, followed by the application of the proper irrigation scheduling in terms of both timing and quantity of water applied and concluding with the choice of the best crop management with regards to the soil and climate conditions.

To efficiently manage water in agriculture, there is need to have a demand management strategy to reduce irrigation at the farm level include supplemental irrigation, deficit irrigation, improved irrigation methods and performance, distribution uniformity, and various soil and water conservation practices; defining demand management for irrigation to be practices and management decisions of a multiple nature, including agronomic, economic and technical[56]. The selection of the proper irrigation system depends on several factors, such as water availability, crop selection, soil characteristics (deep percolation, runoff, evaporation rate and topography) and the associated installation and maintenance costs [57]. Given the physical geography of Africa, Moris et al, [58] believes large irrigation systems are, however, no solution to the African problem. On contrary, Falkenmark suggests socio-economic 
development of semi and arid lands in Africa and many parts of the world, so that the community will able to utilize rainwater, and master the fluctuating rain [59].

More so, the work of Gebrehiwot et al [60] considered diversification of crops, changing planting dates, soil conservation, increasing rainwater capture and planting trees as important adaptation measures to growing water scarcity in Agriculture in many parts of Africa particularly in Horn and East Africa. Bashir et al [61] observes slowing down population growth, increase investment in the water resources sector and reduce inefficiency and wastage in water use through effective water management and improved technologies as important measures in counteracting water stress in Africa.

According to Falkenmark work [62], to minimize water scarcity and sustain development activities in many parts of Africa and World, water management strategy should be developed which allows the concurrent utilization and conservation of land and water resources. In other words, what is required is environmentally sound and effective management of land and water resources. Such approach should include conservation to increase infiltration of rain and its retention in the root zone, and water conservation to make the best possible use of local rain to mitigate the effects of landscape desiccation and water stress. Pereira et al [63] describes the development of new sources of water supply such saline ground water, use of inferior quality water for irrigation, increased storage capacity, improved conveyance and distribution systems, enhanced operation and maintenance of water infrastructure as important measures in improving water security in many water stress areas.

More so, Bashir et al [64] suggests institutional reform and development to be made in all African countries to pursued with the objective of achieving efficiency and effectiveness in water resources management through decentralization of management functions and provision of mechanisms for enhancing coordination, partnership and accountability

However, the adaptation measures can be implemented in isolation or in combination with other policies or strategies. Dealing with water scarcity requires a complementary approach of supply and demand management as well as on-farm and off-farm measures. Adaptations strategies can be framed and implemented not only at temporal scales, but can also have a range of spatial scales, from local to regional and to national [65].

\section{CONCLUSION}

There is high need to ensure policy alignment on food- water nexus, and water rights for different sectors to sustainable manage water resources. As African countries need to further development, harmonization of interests and polices is required to address both the need to maintain agricultural and industrial development activities that consume more water with conservation and sustainability of freshwater. Agriculture and food security policies have to be strongly connected to water policies and that degree of connection needs to be appreciated by all sectors to ensure overall coherence. Also bold measures have to be taken against climate change as it results in depletion of ground water resources through escalation of evaporation, and change 
of precipitation. Efficient rainwater harvesting at household, farm, and communal level is needed. Also farmer communities that fail to efficiently utilize rainwater should be trained on different methods in rainwater harvesting. Poverty alleviating initiatives should be increased in attempt to empower communities to corporately work on community based water development activities. Farmers should be trained on different agronomic practices that reduce water consumption. And most importantly land use management is needed in areas that encounter water stress in Africa, to address the impact of land degradation on water resource.

\section{ACKNOWLEDGEMENTS}

I would like to thank Dr. Maria Mbbtitude and Danzon Musinguzi for reviewing this work. I am very grateful for the work done.

\section{CONFLICT OF INTERESTS}

The author has not declared any conflict of interests. All the scholarly and academic information used in this paper have been fully and dully cited and referenced.

\section{REFERENCES}

1. Falkenmark, M. \&Rockstrom, J. (2004). Balancing Water for Humans and Nature: The New Approach to Ecohydrology. Earthscan, London, UK

2. Falkenmark. "The massive water scarcity threatening Africa-why isn't it being addressed." Ambio 18, no. 2 (1989): 112-118.

3. Findings presented at conference on water scarcity in Africa: Issues and Challenges; Paris, France 2012.

4. Elizabeth Hunt, ( 2008) Thirty of Planet: Strategies for sustainable Water Management, First Edition, published by ZED BOOK, UK

5. HanjraMunir and Qureshi Mohammed (2010) Global water crisis and future food security in an era of climate change, retrieved from Open Research library, Australian National University(ANU) July,2017.

6. Jiménez Cisneros, B.E.; Oki, T.; Arnell, N.W.; Benito, G.; Cogley, J.G.; Döll, P.; Jiang, T.;Mwakalila, S.S. Freshwater resources. In Climate Change 2014: Impacts, Adaptation, and Vulnerability. Part A: Global and Sectoral Aspects. Contribution of Working Group II to the Fifth Assessment Report of the Intergovernmental Panel on Climate Change; Field, C.B., Barros, V.R., Dokken, D.J., Mach, K.J., Mastrandrea, M.D., Bilir, T.E., Chatterjee, M., Ebi, K.L., Estrada, Y.O.,Genova, R.C., et al. Eds.; Cambridge University Press: Cambridge, UK and New York, NY, USA, 2014; pp. 229-269

7. Postel, S.1996. Dividing the waters: Food security, Ecosystem Health, and the new politics of scarcity. Worldwatch Paper 132, September. Washington.pp.14-15

8. Ibid, 1

9. Ibid,2

10. IPCC, 2007: Climate Change 2007: Synthesis Report. Contribution of Working Groups I, II and III to the Fourth Assessment Report of the Intergovernmental Panel on Climate 
Change [Core Writing Team, Pachauri, R.K and Reisinger, A. (eds.)]. IPCC, Geneva, Switzerland, $104 \mathrm{pp}$

11. World Wide Fund for 2017 : http://wwf.panda.org/our_work/forests/deforestation_fronts/deforestation_in_the_congo_ basin/

12. Ibid, 4

13. D.S.G Thomas \& N.J Middleton (1994). Desertification: Exploding the Myth. John Wiley and Sons, England/UK.

14. Chouhan, T.S 1992. Desertification in the world and Its control. Sceintific Publishers, Jodhpur, India

15. Ibid,4

16. M. Hulme, R. Doherty, T. Ngara, M. New and D. Lister. African climate change: 19002100. climate research 17, 145168, 2001.

17. Y. Malhi and J. Wright. Spatial patterns and recent trends in the climate of tropical forest regions. Phil. trans. roy. soc. b, 359(1443), 311-329, 2004

18. A. c. Kruger and S. Shongwe. Temperature trends in South Africa: 1960-2003. international Journal of climatology. 24(15), 1929-1945, 2004

19. new et al. Evidence of trends in daily climate extremes over Southern and West Africa, Journal of geophysical research - Atmospheres, 111, 2006

20. S. M. King'uyu, L. A. Ogallo and E. K. Anyamba. Recent trends of minimum and maximum surface temperatures over eastern Africa. Journal of climatology 13, 28762886, 2000.

21. Gordon Conway 2009: The science of climate change in Africa: Impacts and Adaptations; Discussion paper No1 published by Grantham institute for climate change, Imperial college London

22. Beck, L. and T. Bernauer, 2011: How will combined changes in water demand and climate affect water availability in the Zambezi river basin? Global Environmental Change, 21(3), 1061-1072

23. Hulme, M., R. Doherty,T. Ngara, M. New, and D. Lister, 2001:African climate change: 1900-2100. Climate Research, 17(2), 145-168

24. Jones, P.D. andA. Moberg, 2003: Hemispheric and large-scale surface air temperature variations: an extensive revision and an update to 2001. Journal of Climate, 16(2), 206223.

25. Kruger,A.C. and S. Shongwe, 2004: Temperature trends in South Africa: 1960-2003. International Journal of Climatology, 24(15), 1929-1945.

26. Schreck, C.J. and F.H.M. Semazzi, 2004: Variability of the recent climate of eastern Africa. International Journal of Climatology, 24(6), 681-701.

27. New, M., B. Hewitson, D.B. Stephenson, A. Tsiga, A. Kruger, A. Manhique, B. Gomez, C.A.S. Coelho, D.N. Masisi, E. Kululanga, E. Mbambalala, F.Adesina, H. Saleh, J. Kanyanga, J. Adosi, L. Bulane, L. Fortunata, M.L. Mdoka, and R. Lajoie, 2006: Evidence of trends in daily climate extremes over southern and west Africa. Journal of Geophysical Research D: Atmospheres, 111(D14), D14102, doi:10.1029/2005JD006289. 
28. Rosenzweig, C., G. Casassa, D.J. Karoly, A. Imeson, C. Liu, A. Menzel, S. Rawlins, T.L. Root, B. Seguin, and P.Tryjanowski, 2007:Assessment of observed changes and responses in natural and managed systems. In: Climate Change 2007: Impacts, Adaptation and Vulnerability. Contribution of Working Group II to the Fourth Assessment Report of the Intergovernmental Panel on Climate Change [Parry, M.L., O.F. Canziani, J.P. Palutikof, P.J. van der Linden, and C.E. Hanson (eds.)]. Cambridg

29. Trenberth, K.E., P.D. Jones, P. Ambenje, R. Bojariu, D. Easterling, A. Klein Tank, D. Parker, F. Rahimzadeh, J.A. Renwick, M. Rusticucci, B. Soden, and P. Zhai, 2007: Observations: surface and atmospheric climate change. In: Climate Change 2007: The Physical Science Basis. Contribution ofWorking Group I to the Fourth Assessment Report of the Intergovernmental Panel on Climate Change [Solomon, S., D. Qin, M. Manning, Z. Chen, M. Marquis, K.B. Averyt, M. Tignor, and H.L. Miller (eds.)]. Cambridge University Press, Cambridge, UK and New York, NY, USA, pp. 236-336.

30. Christy, J.R., W.B. Norris, and R.T. McNider, 2009: Surface temperature variations in east Africa and possible causes. Journal of Climate, 22(12), 3342-3356

31. Collins, J.M., 2011: Temperature variability over Africa. Journal of Climate, 24(14), 3649-3666.

32. Grab, S. and A. Craparo, 2011: Advance of apple and pear tree full bloom dates in response to climate change in the southwestern Cape, SouthAfrica: 1973-2009. Agricultural and Forest Meteorology, 151(3), 406-413.

33. Hoffman, M.T., M.D. Cramer, L. Gillson, and M.Wallace, 2011: Pan Evaporation and wind run decline in the Cape Floristic Region of South Africa (1974-2005): implications for vegetation responses to climate change. Climatic Change, 109(3-4), 437-452

34. Mohamed, A.B., 2011: Climate change risks in Sahelian Africa. Regional Environmental Change, 11(Suppl. 1), 109-117.

35. Stern, D.I., P.W. Gething, C.W. Kabaria, W.H. Temperley, A.M. Noor, E.A. Okiro, G.D. Shanks, R.W. Snow, and S.I. Hay, 2011: Temperature and malaria trends in highland EastAfrica. PLoS ONE, 6(9), e24524, doi:10.1371/journal.pone.0024524

36. Funk, C., J. Michaelsen, and M. Marshall, 2012: Mapping recent decadal climate variations in precipitation and temperature across Eastern Africa and the Sahel. In: Remote Sensing of Drought: Innovative Monitoring Approaches [Wardlow, B.D., M.C.Anderson, and J.P.Verdin (eds.)]. CRC Press, Boca Raton, FL, USA, pp. 331-358.

37. Nicholson, S.E., D.J. Nash, B.M. Chase, S.W. Grab, T.M. Shanahan, D. Verschuren, A. Asrat,A.-M. Lézine, and M.Umer, 2013:Temperature variability overAfrica during the last 2000 years. Holocene, 23(8), 1085-1094.

38. Ibid, 30

39. Beck, L. and T. Bernauer, 2011: How will combined changes in water demand and climate affect water availability in the Zambezi river basin? Global Environmental Change, 21(3), 1061-1072.

40. Milzow, C.,V. Burg, andW. Kinzelbach, 2010: Estimating future ecoregion distributions within the Okavango DeltaWetlands based on hydrologicalsimulations and future climate and development scenarios. Journal of Hydrology, 381(1-2), 89-100. 
41. Wolski, P., M.C. Todd, M.A. Murray-Hudson, and M. Tadross, 2012: Multi-decadal oscillations in the hydro-climate of the Okavango River system during the past and under a changing climate. Journal of Hydrology, 475, 294-305.

42. IPCC, 2014: Summary for policymakers. In: Climate Change 2014: Impacts,Adaptation, and Vulnerability. Part A: Global and Sectoral Aspects. Contribution of Working Group II to the Fifth Assessment Report of the Intergovernmental Panel on Climate Change [Field, C.B., V.R. Barros, D.J. Dokken, K.J. Mach, M.D. Mastrandrea, T.E. Bilir, M. Chatterjee, K.L. Ebi, Y.O. Estrada, R.C. Genova, B. Girma, E.S. Kissel, A.N. Levy, S. MacCracken, P.R. Mastrandrea, and L.L.White (eds.)]. Cambridge University Press, Cambridge, United Kingdom and New York, NY, USA, pp. 1-32.

43. World Population Review 2018, http://worldpopulationreview.com/continents/subsaharan-africa-population/

44. Falkenmark M. 2013: Growing water scarcity in agriculture: futurechallenge to global water security. Phil Trans R Soc A 371: 20120410.

45. The researcher encountered in many villages in Somaliland, Somalia or Djibouti that suffer from water scarcity moreover they receive substantial rainwater. This is always considered due to limited technological capacity in efficiently harvesting rainwater.

46. Ibid, 43

47. The researcher encountered such scenarios as he travels to fields in different locations in Somaliland.

48. Robyn Smith (2017): The Water Scarcity-Conflict Nexus; The Case of Darfur; Stellenbosch University, South Africa

49. Randolph Barker Barbara van Koppen and Tushaar Shah 2017: Water Scarcity and Poverty; http://www.povertyenvironment.net/content/water-scarcity-and-poverty

50. Comprehensive Assessment of Water Management in Agriculture (2007). Water for Food Water forLife: A Comprehensive Assessment of Water Management in Agriculture. London: Earth Scanand Colombo: International Water Management Institute.

51. D. Bashir (2017): Water Resource Management in Africa; National Water Resource institute, Kaduna Nigeria

52. Seo, S.N.,2011.Ananalysisofpublicadaptationtoclimate change usingagricultural water schemes in South America.Ecological Economics. 70, 825-834.

53. Pereira, L.S., Oweis, T., Zairi, A., 2002. Irrigation managementunder water scarcity; AgriculturalWater Management. 57, 175-206.

54. Trinh,L.T.,Duong,C.C.,Steen,P.V.D.,Lens,P.N.L.,2013.Exploring thepotentialfor wastewater reuseinagriculture asaclimatechangeadaptationmeasureforCanThoCity, Vietnam. AgriculturalWater Management. 128, 43-54.

55. Noemi Mancusu., Richard L., GavriilKyraikakis., and DonetellaSpano., 2015: Water scarcity and Future Challenges for food production, Department of Science for nature and Environmental Resources, Universityof Sassari, Italy

56. Ibid, 54

57. Ibid, 56 
58. J. Moris, 'Irrigation as a privileged solution in Africandevelopment', Development Policy Review, Vol 5, 1987, pp 99-123.

59. Gebrehiwot,T., vanderVeen,A., 2013.Farm leveladaptation to climatechange: The caseof farmer's in theEthiopianhighlands. EnvironmentalManagement. 52, 29-44.

60. MalinFalkenmark., Jan Lundqvist., and Carl Widstrand., 1989: Macro-scale water scarcity requires Micro-scale approaches; Aspects of vulnerabity in semi arid development; Butterworth \& Co publishers

61. Ibid, 51

62. Ibid, 61

63. Ibid, 54

64. Ibid, 51

65. Bonsal, B.R., Wheaton, E.E., Chipanshi, A.C., Lin, C., Sauchyn, D.J., Wen, L., 2011. Droughtresearch in Canada: Areview. Atmosphere-Ocean. 49, 303-319. 